\title{
HUBUNGAN TINGKAT PENGETAHUAN DENGAN TINGKAT KEPATUHAN PENGOBATAN PADA PASIEN TUBERKULOSIS DI RS MEDIKA DRAMAGA
}

\author{
Karuma Barza A. ${ }^{*}$, Enrawani Damanik², Restu Wahyuningsih ${ }^{3}$ \\ 1. Program Studi Farmasi Sekolah Tinggi Teknologi Industri dan Farmasi Bogor \\ 2. Rumah Sakit Medika Dramaga \\ 3. Mahasiswa Program Studi S1 Farmasi Sekolah Tinggi Teknologi Industri dan Farmasi Bogor \\ Korespondensi: karumabarza.apt@gmail.com
}

\begin{abstract}
ABSTRAK
Tuberkulosis adalah sebuah penyakit yang mudah menular yang disebabkan oleh Mycobacterium tuberculosis. Di Indonesia penyakit TB paru masih menjadi sebuah masalah kesehatan di tengah masyarakat. Untuk mencapai kesembuhan diperlukan pengetahuan yang baik dan keteraturan kepatuhan pengobatan. Tujuan dari penelitian ini yaitu untuk mengetahui hubungan tingkat pengetahuan dengan tingkat kepatuhan pengobatan pada pasien TB paru di RS Medika Dramaga. Penelitian ini menggunakan metode kuantitatif obeservasional. Populasi penelitian diambil dari seluruh pasien TB paru di RS Medika Dramaga. Sampel penelitian ini menggunakan 72 responden dengan instrumen kuesioner. Analisa data penelitian yang dilakukan antara lain analisa univariat dan bivariat dengan metode uji Chi-square. Hasil penelitian menunjukkan tidak memiliki hubungan signifikan antara tingkat pengetahuan dengan kepatuhan pengobatan pada pasien tuberculosis di RS Medika Dramaga dengan nilai Chi-square table 0,800.
\end{abstract}

\section{Kata Kunci: Pengetahuan, Kepatuhan, Tuberkulosis Paru}

\begin{abstract}
Tuberculosis is a contagious disease caused by Mycobacterium tuberculosis. In Indonesia Pulmonary TB is still a health problem in society. To achieve a cure requires good knowledge and regularity of medication adherence. The research objective was to determine the relationship between the level of knowledge and the level of treatment adherence in tuberculosis patients at Medika Dramaga Hospital. This study used a quantitative obeservasional study with a cross sectional approach. The population was taken from all tuberculosis patients at Medika Dramaga Hospital. The sampling technique used purposive sampling with a number of respondents 72 samples using a questionnaire instrument. Data analysis used univariate and bivariate analysis with the chi-square test method. The results showed that there was no significant relationship between the level of knowledge and treatment adherence in tuberculosis patients at Medika Dramaga Hospital with a chi-square table value of 0.800 .
\end{abstract}

\section{Keywords: Knowledge, Compliance, Tuberculosis}




\section{PENDAHULUAN}

Mycobacterium tuberculosis merupakan bakteri aerob yang dapat hidup pada organ paruparu manusia yang menjadi penyebab dari penyakit TB paru. Penularan lebih sering terjadi pada malam hari, hal tersebut disebabkan bakteri ini tidak dapat bertahan terhadap paparan sinar ultraviolet.

Berdasarkan laporan Riskesdas tahun 2018 sebanyak 566.623 kasus TB paru terjadi di Indonesia, angka ini lebih tinggi apbila dibandingkan dengan data tahun sebelumnya. Provinsi Jawa Barat mnejadi wilayah yang memiliki kasus TB paru tertinggi, dimana merupakan provinsi dengan kepadatan penduduk serta kelembaban cukup tinggi.

Obat Anti Tuberkulosis (OAT) terdiri kombinasi beberapa antibiotik yaitu: isoniazid $(\mathrm{H})$, rifampisin $(\mathrm{R})$, pirazinamid $(\mathrm{Z})$, etambutol (E). Dengan masa terapi pengobatan selama enam bulan berturut-turut tanpa henti dan OAT yang diminum secara rutin. Keberhasilan suatu pengobatan TB Paru sangat ditunjang oleh tingkat pengetahuan dan kepatuhan dalam pengobatan dengan dosis dan aturan pakai yang ditetapkan. Bila pengetahuan dan kepatuhan pasien tentang penyakit TB Paru kurang selama masa pengobatan maka, dapat menyebabkan kuman TB menjadi resistensi dan mempengaruhi lamanya pengobatan, begitu juga sebaliknya.

\section{METODE PENELITIAN}

Penelitian ini menggunakan metode kuantitatif observasional menggunakan kuesioner sebagai instrumen penelitian. Penelitian ini menggunakan seluruh pasien TB paru di Instalasi Rawat Jalan Rumah Sakit Medika Dramaga sebagai populasi penelitian yang kemudian dihitung dengan rumus slovin.

Sampel penelitian berjumlah 72 responden, dengan menggunakan metode purposive sampling dengan kriteria yang telah disesuaikan dengan keperluan penelitian.

Kriteria inklusi penelitian ini yaitu pasien rawat jalan TB paru yang berusia 17-55 tahun dan telah menggunakan OAT minimal 2 bulan di Rumah Sakit Medika Dramaga. Kriteria eksklusi penelitian ini yaitu pasien yang memiliki kendala dalam berkomunikasi, pasien gangguan mental dan responden yang tidak mengisi kuesioner dengan lengkap.

Data primer penelitian ini didapatkan dari instrumen kuesioner. Dilakukan uji validitas dan reliabilitas terhadap instrumen penelitian pada 30 responden dengan hasil nilai $r$ hitung $(0,444)$ dan nilai Cronbach Alpha 0,876. Analisa data penelitian yang dilakukan antara lain analisa univariat dan bivariat dengan metode uji chisquare.

\section{HASIL DAN PEMBAHASAN Analisis Univariat}

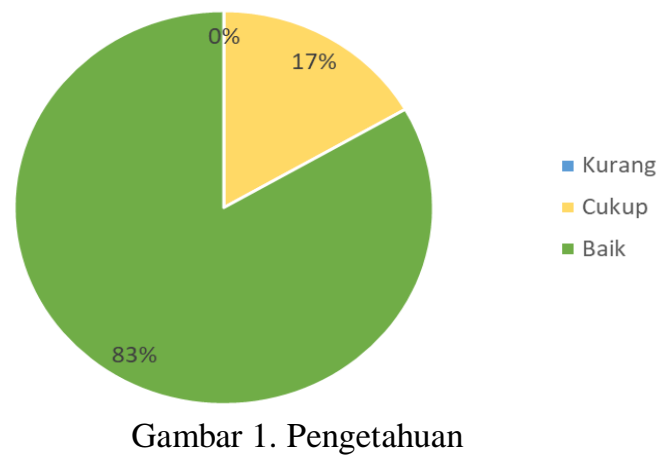

Berdasarkan hasil penelitian terhadap 72 responden di RS Medika Dramaga, menunjukkan bahwa tingkat pengetahuan reponden pada pengetahuan baik sebanyak $83 \%$, pada responden pengetahuan cukup sebanyak $17 \%$ dan tidak terdapatnya responden yang pengetahuan kurang atau $0 \%$.

Pendidikan merupakan salah satu faktor paling penting dalam mengakses informasi, dalam hal ini yaitu pengetahuan terkait pengobatan yang berkaitan terhadap kepatuhan pasien. Semakin tinggi pendidikan akan mempermudah seseorang untuk mengakses informasi terkait pengobatan TB paru.

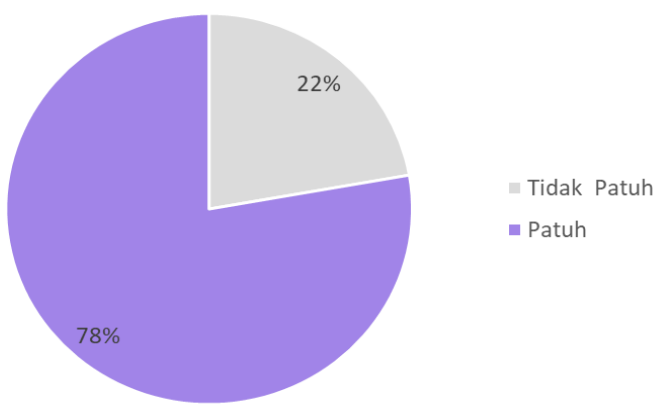

Gambar 2. Kepatuhan

Berdasarkan hasil penelitian terhadap 72 responden di RS Medika Dramaga, menunjukkan bahwa kepatuhan responden pengobatan TB Paru sebanyak 56 responden (78\%) patuh, dan 16 responden (22\%) tidak patuh.

Sementara itu ketidakpatuhan dalam pengobatan TB Paru disebabkan penderita 
merasa bingung pada saat meminum obat atau waktu untuk meminum obat yang tidak konsisten akibat aktivitas sehari-hari yang cukup menyibukkan responden. Hal ini dapat dipengaruhi oleh keterbatasan pengetahuan terkait pentingnya kepatuhan dan risiko yang mungkin dapat terjadi apabila terjadi ketidak patuhan dalam pengobatan TB paru.

\section{Analisis Bivariat}

Analisis untuk membuktikan kebenaran hipotesis hubungan antara pengetahuan responden TB Paru dengan kepatuhan responden dalam menjalani pengobatan yaitu menggunakan Uji Chi-square dengan taraf signifikansi 0,05 .

\section{Tabel 1. Hasil Chi Square Usia terhadap Kepatuhan}

\begin{tabular}{ccccc}
\hline Usia & \multicolumn{2}{c}{ Kepatuhan } & Total & $\begin{array}{c}\text { Nilai } \\
\text { Signifikansi }\end{array}$ \\
& Tidak Patuh & Patuh & & \\
\hline 17-25th & 5 & 14 & 19 & \\
26-35th & 8 & 24 & 32 & 0,60 \\
36-45th & 2 & 16 & 18 & \\
$46-55$ th & 1 & 2 & 3 & \\
\hline
\end{tabular}

Berdasarkan data hubungan antara usia pasien dengan kepatuhan pengobatan pasien dengan usia produktif terutama pada usia 26-35 tahun. Hal ini disebabkan usia produktif lebih sering beraktifitas di luar sehingga memiliki risiko tertular bakteri TB paru lebih tinggi, kualitas udara yang buruk di perkotaan juga dapat menurunkan kualitas paru-paru mengingat Kota Bogor memiliki tingkat kepadatan kendaraan bermotor yang tinggi. Dari hasil pengelolaan data didapatkan hasil uji Chi-square sebesar $0,60>0,05$.

Tabel 2. Hasil Chi Square Jenis Kelamin terhadap Kepatuhan

\begin{tabular}{ccccc}
\hline Jenis Kelamin & \multicolumn{2}{c}{ Kepatuhan } & Total & $\begin{array}{c}\text { Nilai } \\
\text { Tidak Patuh }\end{array}$ \\
Laki-laki & Patuh & & Signifikansi \\
& 10 & 33 & 43 & \\
Perempuan & $(23,3 \%)$ & $(76,7 \%)$ & & 0,79 \\
& 6 & 23 & 29 & \\
& $(20,7 \%)$ & $(79,3 \%)$ & & \\
\hline
\end{tabular}

Berdasarkan data Tabel.2 pasien memiliki aktivitas pekerjaan di luar rumah yang perempuan memiliki presentase tingkat dapat menyebabkan ketidakpatuhan. Hasil uji kepatuhan yang lebih tinggi $(79,3 \%)$ yang dilakukan didapatkan Chi-square sebesar dibandingkan dengan pasien pria, hal ini dapat $0,79>0,05$. disebabkan karena pria pada pada umumnya 
Tabel 3. Hasil Chi Square Pendidikan Akhir terhadap Kepatuhan

\begin{tabular}{ccccc}
\hline \multirow{2}{*}{ Pendidikan } & \multicolumn{2}{c}{ Kepatuhan } & Total & $\begin{array}{c}\text { Nilai } \\
\text { Signifikansi }\end{array}$ \\
\cline { 2 - 3 } & Tidak Patuh & Patuh & & \\
\hline Tidak tamat SD & 0 & 0 & 0 & \\
SD & 0 & 1 & 1 & \\
SMP & 2 & 6 & 8 & \\
SMA & 9 & 31 & 40 & 0,95 \\
Perguruan Tinggi & 5 & 18 & 23 & \\
\hline
\end{tabular}

Responden paling banyak merupakan tamatan SMA, sehingga perihal informasi dan edukasi bukan menjadi permasalahan dalam memahami pengetahuan tentang pengobatan TB paru. Berdasarkan data hubungan antara pendidikan akhir pasien dengan kepatuhan pengobatan TB paru didapatkan hasil uji Chisquare sebesar $0,95>0,05$.

Tabel 4. Hasil Chi Square Pekerjaan Terhadap Kepatuhan

\begin{tabular}{ccccc}
\hline \multirow{2}{*}{ Pekerjaan } & \multicolumn{2}{c}{ Kepatuhan } & Total & $\begin{array}{c}\text { Nilai } \\
\text { Signifikansi }\end{array}$ \\
\cline { 2 - 3 } & Tidak Patuh & Patuh & & \\
\hline PNS & 0 & 5 & 5 & \\
Karyawan Swasta & 8 & 17 & 25 & 0,60 \\
Wirausaha & 4 & 18 & 22 & \\
Tidak Bekerja & 4 & 16 & 20 & \\
\hline
\end{tabular}

Responden didominasi oleh pegawai kantoran baik itu sebagai PNS, karyawan swasta ataupun wirausaha. Berdasarkan data hubungan antara pekerjaan pasien dengan kepatuhan

pengobatan TB paru didapatkan hasil uji Chisquare sebesar 0,60 dimana lebih besar dari 0,05 .

Tabel 5. Hasil Chi Square Pengetahuan Terhadap Kepathuan

\begin{tabular}{ccccc}
\hline \multirow{2}{*}{ Pengetahuan } & \multicolumn{2}{c}{ Kepatuhan } & Total & $\begin{array}{c}\text { Nilai } \\
\text { Signifikansi }\end{array}$ \\
\cline { 2 - 3 } & Tidak Patuh & Patuh & & \\
\hline Cukup & 3 & 9 & $\mathbf{1 2}$ & \\
& $(25 \%)$ & $(75 \%)$ & & 0,80 \\
Baik & 13 & 47 & $\mathbf{6 0}$ & \\
& $(21,7 \%)$ & $(78,3 \%)$ & & \\
Total & $\mathbf{1 6}$ & $\mathbf{5 6}$ & $\mathbf{7 2}$ & \\
\hline
\end{tabular}


Dari data hubungan pengetahuan dan kepatuhan pasien di atas terdapat $21,7 \%$ responden dengan pengetahuan baik terhadap informasi pengobatan dan risiko resistensi antibiotik dalam pengobatan TB paru. Ketidakpatuhan kemungkinan terjadi disebabkan oleh berbagai macam hal, antara lain yaitu kurang lengkapnya informasi yang diberikan oleh petugas kefarmasian terkait cara penggunaan obat serta risiko resistensi, kurangnya kesadaran akan bahaya resistensi antibiotik walaupun sudah memiliki pengetahuan yang baik tentang resistensi antibiotik, dan kurangnya dukungan dari lingkungan sekitar baik keluarga atau kerabat dalam meningkatkan kesadaran kepatuhan pengobatan TB paru mengingat lamanya pengobatan yang dijalani oleh pasien sehingga semangat menjadi pasang surut.

Berdasarkan data hubungan antara pengetahuan pasien terhadap pengobatan dan risiko resistensi dalam pengobatan $\mathrm{TB}$ paru dengan kepatuhan pengobatan pada pasien TB paru di Rumah Sakit Medika Dramaga didapatkan hasil uji Chi-square sebesar 0,80> 0,05 .

Dari hasil uji Chi-square yang dilakukan menunjukkan bahwa tidak memiliki hubungan yang signifikan antara keseluruhan variabel terhadap kepatuhan dalam pengobatan TB paru.

\section{SIMPULAN}

1. Tingkat pengetahuan pasien tentang TB Paru di RS Medika Dramaga diperoleh sebanyak 60 responden $(83 \%)$ yang pada umumnya memiliki tingkat pengetahuan kategori tinggi, dan sebanyak 12 responden $(17 \%)$ dengan tingkat pengetahuan kategori sedang.

2. Tingkat kepatuhan pasien mengkomsumsi obat anti tuberkulosis (OAT) di RS Medika Dramaga diperoleh sebanyak 56 responden (78\%) yang patuh dalam pengobatan TB Paru, dan sebanyak 16 responden (22\%) lainnya yang tidak patuh dalam pengobatan TB Paru.

3. Nilai signifikansi dari uji Chi Square yaitu 0,80 lebih besar dari $(0,05)$. Hasil nilai signifikansi dari uji Chi Square dapat disimpulkan menerima Ho yaitu tidak terdapat hubungan bermakna antara pengetahuan dengan tingkat kepatuhan pengobatan pada pasien TB Paru di Rumah Sakit Medika Dramaga.

\section{DAFTAR PUSTAKA}

[1] Adam, Lusiane. 2020. Pengetahuan Penderita Tuberkulosis Paru Terhadap Kepatuhan Minum Obat Anti Tuberkulosis. [Jurnal]. Gorontalo: Poltekkes Kemenkes Gorontalo.

[2] Afandi, N. 2017. Faktor Yang Berhubungan dengan Kepatuhan Berobat Pada Pasien TB Paru dengan Pendekatan Theory of Planned Behavior. [Skripsi]. Surabaya: Universitas Airlangga.

[3] Atik, Ade. 2013. Hubungan Pengetahuan Penderita Tentang Tuberkulosis Paru dengan Perilaku Kepatuhan Minum Obat Di Puskesmas Curug Tangerang. [Jurnal]. Jakarta Barat. Universitas Esa Unggul.

[4] Dhewi, G. I, Armiyati, Y dan Supriyono, M. 2011. Hubungan antara Pengethuan, Sikap Pasien dan Dukungan Keluarga dengan Kepatuhan Minum Obat Pada Pasien TB Paru di BKPM Pati. [Artikel Ilmiah]. Semarang: STIKES Telogorejo Semarang.

[5] Gunawan, A.R.S; Simbolon, R.L; Fauzia, D. 2017. Faktor-faktor yang mempengaruhi Tingkat Kepatuhan Pasien Terhadap Pengobatan Tuberkulosis Paru Di Lima Puskesmas Se-Kota Pekanbaru. [Jurnal]. Pekanbaru.

[6] Hayati, A. 2011. Evaluasi Kepatuhan Minum Obat Penderita Tuberkulosis Paru Tahun 2010-2011 di Puskesmas Kecamatan Pancoran Mas Depok. [Skripsi]. Depok: Universitas Indonesia.

[7] Istiqlal, I. N. 2019. Gambaran Pengetahuan Pasien Tuberkulosis Paru Tentang Kepatuhan Minum Obat Di UPT Puskesmas Mantup Kabupaten Lamongan. [Jurnal]. Lamongan: Universitas Muhammadiyah Lamongan.

[8] Nurhaini, R; Hidayati, N; Oktavia, W.N. 2019. Gambaran Kepatuhan Minum Obat Pasien Tuberculosis Di Balai Kesehatan Masyarakat (BALKESMAS) Wilayah Klaten. [Jurnal]. STIKES Muhammadiyah Klaten 3. 
47 Karuma Barza A et al., (Hubungan Tingkat Pengetahuan Dengan Tingkat ...)

[9] Octavienty; Hafiz, Ihsanul; Khairani T.N. 2019. Hubungan Tingkat Pengetahuan Terhadap Kepatuhan Minum Obat Pada Pasien Tuberkulosis Paru (TB) Di UPT

Puskesmas Simalingkar Kota Medan.

[Jurnal]. Medan. Institut Kesehatan Helv 